\section{Kenny Ade' Soyemi}

Department of Accounting

Faculty of Administration

and Management Sciences

Olabisi Onabanjo University

Ago Iwoye, Ogun State, Nigeria

k.ade.soyemi@gmail.com

\section{Lateef Adewale Yunusa}

Department of Banking and Finance

Faculty of Administration

and Management Sciences

Olabisi Onabanjo University

Ago Iwoye, Ogun State, Nigeria

yunusalateef@gmail.com

\section{Olusola Enitan Olowofela}

Department of Banking and Finance

Faculty of Administration

and Management Sciences

Olabisi Onabanjo University

Ago Iwoye, Ogun State, Nigeria

olowofelaolusola@gmail.com

(corresponding author)

\title{
Financial inclusion and sustainable development in Nigeria
}

Accepted by Editor Ewa Ziemba | Received: October 27, 2018 | Revised: February 12, 2019; May 9, 2019; May 30, 2019, June 20, 2019; July 27, 2019, September 18, 2019; October 14, 2019, October 26, 2019; November 7, 2019 | Accepted: November 12, 2019.

\begin{abstract}
Aim/purpose - Financial inclusion is a catalyst for achieving sustainable development. This study attempts to evaluate impact of financial inclusion on sustainable development.

Design/methodology/approach - Both Error Correction Model (ECM) and Fully Modified Ordinary Least Square (FMOLS) were used to ascertain the short-run and long-run relationship respectively among the variables which covers the period from 2001 to 2016, as data for HDI (Human Development Index) were available for Nigeria from 2001 through 2016 only.

Findings - The result of the analysis indicated that in the short-run there is short-run causality running from a number of commercial bank branches, demand deposit from the rural areas, loan to rural areas to HDI. The long-run result revealed that the explanatory variables consisting of loan to rural areas, number of commercial bank branches and demand deposit from the rural areas all have positive significant impact on HDI in Nigeria. The overall result revealed that financial inclusion has impact on sustainable development in Nigeria.
\end{abstract}

Cite as: Soyemi, K. A., Olowofela, O. E., \& Yunusa, L. A. (2020). Financial inclusion and sustainable development in Nigeria. Journal of Economics \& Management, 39(1), 105-131. https://doi.org/10.22367/jem.2020.39.06 
Research implications/limitations - The study recommends that banks and monetary authorities should develop new product and services that will attract savings from the rural dwellers because of the level of significance of their deposit to the development of the country. All the more so as commercial banks should also ensure that the rural dwellers are provided with more bank branches, most especially, in areas where there are few or no banks. Credit facilities should also be provided to the people at an affordable rate as this will uplift the level of inclusion and reduce the level of exclusion in the country which will improve the sustainable development in the country.

Originality/value/contribution - Empirically, the study attempted to investigate the impact of financial inclusion on sustainable development in Nigeria. The results of the study suggest that government should continue its effort in the area of poverty alleviation by embracing financial inclusion via a vis financial institutions introducing new financial product and services at lower cost that will cater for the disadvantaged group in the society.

Keywords: sustainable development, financial inclusion, poverty alleviation.

JEL Classification: G21, P33, N27.

\section{Introduction}

A well-organised financial system helps distribute income equally, reduce poverty, include the excluded population into the formal financial system and protect them against economic shocks (Reserved Bank of India [RBI], 2008; World Bank, 2008). Sustainable Development Goals (SDGs) were coined out of Millennium Development Goals (MDGs) as a result of the hardship encountered by most countries in achieving the MDGs which focused on poverty reduction, education for all, gender equality and women empowerment, child mortality reduction, improved maternal health, combating HIV/AIDS, malaria and other diseases, ensuring environmental sustainability and development of a global partnership for development (United Nation, 2017). As a result of the challenges encountered in the achievement of MDGs, SDGs were used to replace MDG, which has 17 goals embedded, which are to be achieved in 2030 .

The United Nations (UN) called the MDG as the most successful antipoverty movement in history but looking at Nigeria situation, the success of the MDG was not felt by the disadvantaged group in the society. The study of Schumpeter (1911) asserted that services provided by financial intermediaries are essential for technological innovation and economic development; financial education should be considered as an essential tool and a vital component of the financial system in general and for the financial intermediaries in particular. Amidžić, Massara, \& Mialou (2014) posited that financial inclusion is when individuals and firms have access to basic financial services. Similarly, the over- 
all goal of sustainable development (SD) is the long-term stability of the economy and environment; this is only achievable through the integration and acknowledgement of economic, environmental and social concerns which is achievable vis a vis financial system (Emas, 2015). Development economists are of the view that improving access and making basic financial services available to all members of the society in order to build an inclusive financial system should be the goal (Sain, Rahman, \& Khanam, 2016). Enhancing the access to and the quality of basic financial services such as availability of credit, mobilisation of savings, insurance and risk management can facilitate sustainable growth and productivity, especially for small and medium scale enterprises. Muhammed $\&$ Wei (2014) observed that in developing countries large proportion of population are dependent on agriculture and reside in the rural areas of these countries; financial intermediation has been poor and is unable to meet sustainable development. Hence, financial inclusion may be the only way to make financial facilities available for the poor at all levels of income in order to achieve sustainable development goals. Nigeria has been involved in financial inclusion since the 1970s when rural banking was introduced moral suasion requiring deposit money banks to open branches in rural areas and there after central bank licensing of people's bank, community bank and present microfinance bank, and subsequently innovations in banks, including e-banking, internet banking, etc. More than 39.7 percent of Nigerians are financially excluded (EFInA Survey, 2012). This suggests that financial development in Nigeria may not have translated to neither inclusive finance nor inclusive growth. The implication is that members of the society, especially the poor, may not be able to access finance for productive employment and human capital development. The failure of financial development to aid inclusive finance may result to increase in poverty levels, especially in a crisis hit economy in the Sub-Sahara African countries (World Bank, 2001). Intensely, whether allowing people to open a bank account or access credit, financial services are certainly very important for economic growth and wealth creation.

Klapper, El-Zoghbi, \& Hess (2016) opine that in India poverty was reduced by 14 up to 17 percentage points as a result of the government effort in opening bank accounts for the people in the rural areas. Invariably, less than one adult out of four in Africa has access to an account at a formal financial institution. People domiciled in the rural part of an economy should be included in the financial system by ensuring that they have a bank account as this will contribute to the GDP of the nation. Beck, Demirgüç-Kunt, \& Honohan (2009) argue that finance is not only pro-growth, but also pro-poor because financial inclusion plays a prominent role in poverty reduction globally. 
Therefore, this level of development in Nigeria motivated this research work. The main objective of this study is therefore to investigate the impact of financial inclusion on sustainable development using both Error Correction Model (ECM) and Fully Modified Ordinary Least Square (FMOLS) to ascertain both the short-run and long-run relationship respectively among the variables. The null hypothesis of the study is that financial inclusion has no significant impact on sustainable development in Nigeria.

The rest of this paper is organised as follows. The second part discusses literature review and part three presents the data and methodological issues. The part four presents the empirical results and the last part concludes.

\section{Literature review}

Financial inclusion is the access to financial services provided by formal financial institutions at an affordable cost which includes the rich, the poor and the low income earners in the economy. Enhancing Financial Innovation $\&$ Access (EFInA) defines financial inclusion as the provision of series of financial services which are necessary for all the adults which include both the poor and the disadvantaged group of the society. Internationally, financial inclusion is seen as the right of every individual to social inclusion, better standard of living, as well as an instrument for empowering the poor in a nation (Banco Central do Brasil, 2010). It has also been defined as "the state of financial system where every member of society has access to appropriate financial products and services for effective and efficient management of their resources; get needed resources to finance their businesses; and financial leverage to take up opportunities that will lead to increase in their income" (Chima, 2011).

Developed and developing countries do face the same issues in terms of financial inclusion, though the inferences between high and low income countries differ. However, in high income countries, financial literacy is correlated with retirement planning, a sophisticated investment behaviour and has macroeconomic implications, while in low income countries, financial literacy is correlated with having a bank account and affects insurance take-up. EFinA Survey (2014) asserted that one of the challenges facing financial inclusion is the rate of population growth. With an annual population growth rate of $3.2 \%$, Nigeria's population is expected to reach 221.4 million by 2020 . With the continuous rise in population, there is also a rise in the number of proportion of low income earners (mostly in rural areas, and especially in the North). While there has been 
significant growth in both bank branches and the banked population, profitability considerations make for a poor geographical correspondence between the growth in banking and the growth in population, leading to the high level of regional variation.

In any case, as demonstrated below, the poorest people make hardly use of banks, so the lack of emphasis on bank branch expansion in the financial inclusion strategy is sensible. Ethics and religious conflict have now also become a major barrier to inclusion, as witnessed by the slowdown in inclusion in the northeast. A further reason for high levels of exclusion in the north, for instance, is the Islamic prohibition of interest, and the population's aversion to interest based finance. Greater inclusion therefore requires financial services based on Islamic Sharia such as those provided by Jaiz Bank Plc, Islamic Micro Finance and Takaful (Insurance). These services can be expanded by linking with mobile money and agent banking, capitalising on the agent networks of mobile phone companies.

The World Bank (2008), as cited in Ibeachu (2010), categorised causes of financial exclusion into the followings: insufficient income, discrimination, contractual/information framework, price and product features. However, Kempson, Atkinson, \& Pilley (2006) gave some explanations to the reasons why people are financially excluded. They said that these reasons could vary from country to country among which are bank required identification and documents which the poor may not have, the terms and conditions of bank accounts, high levels of bank charges, physical access, unemployment and low income, lack of financial education, lack of mobile banking, and cultural barriers in financial inclusion.

Eliminating extreme poverty has been one of the core objectives of SDG's across all the UN member countries. Banerjee \& Newman (1994), Galor \& Zeira (1993), Aghion \& Bolton (1997) and Beck, Demirgüç-Kunt, \& Levine (2007) asserted that difficulty encountered in accessing financial products and services can increase the poverty rate in the country. Inability of most individuals to access basic financial products and services has made life difficult for most people. Access to financial services can boost the productive capacity of individuals and at the same time increase net savings of a country(Aportela, 1999; Ashraf, Karlan, \& Yin, 2010). Individual savings help the people in hard time, acquisition of asset and human capital through savings helps in poverty reduction (Brune, Giné, Goldberg, \& Yang, 2015; Dupas \& Robinson, 2013; Karlan, Ratan, \& Zinman, 2014; Pande, Cole, Sivasankaran, Bastian, \& Durlacher, 2012). In addition, the recent digital method of payment has reduced the poverty rate by enabling people to get money from their siblings and friends at far distance. Jack \& Suri (2014) reported that users of digital means of payment are found to have access 
to fund than non-user in time of financial shocks or crises. However, Nigeria Bureau of Statistics (2010) reported that more than $60 \%$ of the Nigerians live below USD 1 per day, $69 \%$ of the total population are reported to be poor and $60 \%$ living in absolute poverty.

Reducing hunger and promoting food security is another objective of the SDGs. Accessibility of farmers to financial services at a low cost determines the productivity of farmers. Farmers who have access to credit at low cost and operate savings account have the tendency of engaging in a larger investment. Brune et al. (2015) reported that cash crop farmers in Malawi with savings account who do not withdraw their money until a stipulated date experienced increase in their investment by 13 percent as well as 21 percent increase in crop output. Fink et al. (2014) reported that the short term credit provided to Zambian farmers increased both output and revenue by 10 percent. Similarly, it was reported that in Mali, loan offered to Malians increased both their expenditure and investment in agricultural input (Beaman, Karlan, Thuysbaert, \& Udry, 2014). Digital financial product was found to be beneficial to farmers in varieties of ways. It has helped the farmers in the payment of salaries and wages, social transfer and agricultural subsidies (Aker, Boumnijel, McClelland, \& Tierney, 2014; Muralidharan, Niehaus, \& Sukhtankar, 2014).

Achieving good health and well-being in all the member countries of the $\mathrm{UN}$ is another objective of SDGs. One of the reasons for increasing the level of poverty in developing countries was found to be money spent by the individual from their personal pocket on their personal health care (Krishna, 2006; Priyanka, Xu, \& Evans, 2011). The money spent on health care reduces the individual resources and income. Pannarunothai \& Mills (1997), as well as Frenk $\&$ Knaul (2002), reported that an inefficient or poorly funded health care places the burden of medical expenses on the people. Innovation of financial service like health insurance scheme could help reduce the risk of health emergency especially in women during pregnancy, childbirth and greater susceptibility to infection. Women's World Banking (2012) asserted that insurance scheme could help minimise the money spent by the individual on health care which could disturb their economic activities and income. In Kenya, savings were discovered to help people in managing health expenses, most especially, the informal medium for saving money apart from formal financial system could help increase health savings by 66 percent (Dupas \& Robinson, 2013).

Fostering quality of education all over the UN countries is another objective of SDGs. Attaining quality education is dependent on the ability of people to invest in acquisition of knowledge. Development of human capital through qual- 
ity education would fasten the pace of development in the country. Low quality education widens the gap between the rich and the poor (O'Neill, 1995). Morduch (2007) as well as Ashraf, Gons, Karlan, \& Yin (2003) reported that a financial product like a short and medium term loan, direct debit and commitment product can help people to meet up with the payment of tuition fees. Ability of people to make payment of tuition fees at home through the digital medium has induced more than 27 percent of participants in the prompt payment of tuition fees (De Arcangelis, Joxhe, McKenzie, Tiongson, \& Yang, 2015).

Another goal of SDG is promoting gender equality. Accesses to formal financial services enables women to regain the economic power which allows gender equality. The majority of women are unemployed and are not ready to work (World Bank, 2015) which leads to income loss as a result of the gender gap between men and women which was estimated to be 15\% in OECD countries, 38\% in both Middle East and North Africa. Better access to financial products and services will enable many women to be self-employed compared to men in developing countries (Demirguc-Kunt, Klapper, \& Singer, 2013). Women pay higher interest on a loan compared to men because of poor credit history or lack of collateral (IFC, 2011). Including women into the formal financial system will help to bridge the inequality gap between men and women (Aker et al., 2014; Ashraf et al., 2010). Digital financial products and services like interest banking, mobile banking help reduce the women exposure to risk of theft, asymmetric information, and competitive risk (Malhotra, Kanesathasan, \& Patel, 2012).

Promoting shared economic growth is one of the SDG objectives. Increase in the number of poor individuals in the financial system reduces the pace of economic growth in the country. Milanovic (2012) reported that across the world income levels have increased in almost all countries of the world. The developed countries recorded reduction in the level of income inequality between rich and poor but the developing countries recorded high level of poverty with 70 percent of the total poor household domiciled in just 10 countries: China, Bangladesh, Ethiopia, the Democratic Republic of Congo, India, Indonesia, Madagascar, Nigeria, Pakistan and Tanzania (IMF, 2015). Financial inclusion promotes financial deepening through the mobilisation of savings which will be used to finance productive economic activities (King \& Levine, 1993). Inversely, financial exclusion widens the gap between the rich and the poor which deepens income inequality, slows the pace of economic growth and increases the level of poverty (Banerjee \& Newman, 1994; Greenwood \& Jovanovic, 1990; World Bank, 2014). However, Somoye (2018) posited that Nigeria has the lowest average HDI (Human De- 
veloped Index) of 0.504 compared with South Africa (0.641), China (0.70), Japan (0.888), the USA (0.913), the UK (0.90), and Australia (0.931).

The use of mobile phone and Information and Communication Technology (ICT) helps achieve economic growth because they are tools of financial inclusion which aid access to financial services in the most areas where the traditional formal financial services are not available (Andrianaivo \& Kpodar, 2011). Another aim of SDG is promoting innovation and sustainable industrialisation. Easy access to credit is a key to promoting innovation and sustainable industrialisation which increases the level of investment in the country. Limited access to financial services is one of the main constraints experienced by most small and medium enterprises (SMEs). Access to credit will boost the establishment of new business and enable expansion of existing ones. The start-up and expansion will create jobs for the unemployed (Klapper et al., 2016). Recent studies revealed that credit enhances the performance of business. Banerjee, Duflo, Glennerster, \& Kinnan (2015) reported that new business will emerge when credit is offered and these firms will spend on business durables. Increased access to credit increases the wealth of the entrepreneur from 5 percent to 10 percent which, at the same time, translates into increasing profit. Attanasio, Augsburg, De Haas, Fitzsimons, \& Harmgart (2011) reported that in Mongolia availability of credit enabled more women to expand their business and invested in small scale business which generated 8.5 percent higher entrepreneur's profit. Skill acquisition only was discovered not to be contributing to business profit but the mixture of skill acquisition and cash payment aimed at inducing credit higher and importantly the increase in business profitability, though this impact dissipated in the second year (de Mel, McKenzie, \& Woodruff, 2014). However, the weakness of the financial market was figured out by the recent global financial crisis which was a result of poor risk management, poor credit appraisal, etc. Economic growth occurs through capital formation and savings mobilisation which translate into an effective and efficient financial sector. Financial inclusion could help prevent the ill functioning of the market mechanism by extending the formal financial service to the poor and disadvantaged group of the society (Islam \& Al Mamun, 2011).

Khan (Financial inclusion and financial stability..., 2011) pointed to three ways through which financial inclusion can contribute to financial stability positively. First, lending to small businesses could help the bank mitigate against the risk in the bank which in the long run reduces volatility and relative size of any single borrower in the overall portfolio and also reduces the inter- 
connectedness' risks of the financial system. Second, an increase in the number of small savers and bank deposit base reduces banks' dependence on 'non-core' financing which is risky during the crisis. Third, greater financial inclusion helps communicate monetary policy to the citizens, which leads to financial stability. Extensively, financial inclusion helps increase the financial system resources by improving the savings culture of the rural populace and plays its own duty in economic development process (Allen, Demirgüç-Kunt, Klapper, \& Martinez Peria, 2012). Further, including the low income earners into the financial system helps protect their wealth and resources in difficulty (Beck, Demirgüç-Kunt, Laeven, \& Maksimovic, 2006).

Financial inclusion helps prevent the poor from the exploitation of the moneylender by ensuring easy access to formal credit. Financial inclusion also ensures the involvement of the excluded population in the financial system; hence financial inclusion ensures their access to the financial system at an affordable cost (Shankar, 2013). Sacerdoti (2005) posited that financial deepening translates into faster economic growth and proved that there is a strong relationship between access to a bank credit and overall economic development of a country. Hannig $\&$ Jansen (2010) posited that low-income earners are quite immune to economic cycles, so that including them in the financial sector will tend to raise the stability of the deposit and loan bases. They note anecdotal evidence that suggests that financial institutions catering to the lower end tend to weather macro-crises well and help sustain local economic activity. The financial inclusion indicators are stated below according to the National Financial Inclusion Strategy (2012):

- Number of bank branches per 100,000 adults/per 1,000 sq km,

- Number of ATMs per 100,000 adults/per 1,000 sq km,

- Number of POS devices 100,000 adults/per 1,000 sq km,

- Number of mobile agent 100,000 adults/per 1,000 sq km,

- Number of men using a payment product and the frequency of use,

- Number of women using a payment product and the frequency of use,

- Number of men using a savings product and the frequency of use,

- Number of women using a savings product and the frequency of use,

- Number of men using a credit product and the frequency of use,

- Number of women using a credit product and the frequency of use,

- Number of men using an insurance product and the frequency of use,

- Number of women using an insurance product and the frequency of use,

- Number of men using a pension product and the frequency of use,

- Number of women using a pension product and the frequency of use, 
- Cost of using channels of developing financial services, e.g. cost of ATM transaction, cost of entry level of credit product/insurance product/ transactional services interest rate spread between savings and credit for low value accounts.

EFInA (2016) report indicated that a very low percentage of the adult population have access to formal financial service in Nigeria. The proportion is analysed in Table 1 below.

Table 1. State of financial inclusion in Nigeria

\begin{tabular}{|c|c|c|c|c|c|}
\hline Year & Banked & Formal others & Informal only & $\begin{array}{c}\text { Financially } \\
\text { excluded }\end{array}$ & $\begin{array}{c}\text { Adult } \\
\text { population }\end{array}$ \\
\hline 2008 & $21.1 \%(18.27)$ & $\begin{array}{r}2.5 \% \\
(2.17)\end{array}$ & $\begin{array}{r}23.9 \% \\
(20.70)\end{array}$ & $\begin{array}{r}52.5 \% \\
(45.62)\end{array}$ & 86.6 \\
\hline 2010 & $\begin{array}{r}30 \% \\
(25.41) \\
\end{array}$ & $\begin{array}{r}6.3 \% \\
(5.34) \\
\end{array}$ & $\begin{array}{r}17.4 \% \\
(14.74)\end{array}$ & $\begin{array}{r}46.3 \% \\
(39.22)\end{array}$ & 84.7 \\
\hline 2012 & $\begin{array}{r}32.5 \% \\
(28.57) \\
\end{array}$ & $\begin{array}{r}10.5 \% \\
(9.23)\end{array}$ & $\begin{array}{r}17.3 \% \\
(15.21) \\
\end{array}$ & $\begin{array}{r}39.7 \% \\
(34.90)\end{array}$ & 87.9 \\
\hline 2014 & $\begin{array}{r}36.3 \% \\
(33.94)\end{array}$ & $\begin{array}{r}12.3 \% \\
(11.50)\end{array}$ & $\begin{array}{r}11.9 \% \\
(11.13)\end{array}$ & $\begin{array}{r}39.5 \% \\
(36.93)\end{array}$ & 93.5 \\
\hline 2016 & $\begin{array}{r}38.3 \% \\
(36.92)\end{array}$ & $\begin{array}{r}10.3 \% \\
(9.93)\end{array}$ & $\begin{array}{r}9.8 \% \\
(9.44)\end{array}$ & $\begin{array}{r}41.6 \% \\
(40.10)\end{array}$ & 96.4 \\
\hline
\end{tabular}

Source: EFInA (2016).

The above table shows the trend in the state of financial inclusion in Nigeria. The proportion of adults who are formally banked increased from $21.1 \%$ in 2008 to $38.3 \%$ in 2016 . The proportion of formal other increased from $2.5 \%$ in 2008 to $10.3 \%$ in 2016 , while the proportion of the informal others reduced from $23.9 \%$ in 2008 to $9.8 \%$ in 2016 , the proportion of adults who were financially excluded from formal financial service accounts for $52.5 \%$ of the population in 2008 , it has continued to decline and was $39.5 \%$ in 2014 and increased to $41.6 \%$ in 2016.

Table 2. Cross country comparison in Africa for 2016

\begin{tabular}{|l|r|r|r|r|}
\hline \multicolumn{1}{|c|}{ Country } & Banked & \multicolumn{1}{c|}{ Formal banked } & \multicolumn{1}{c|}{ Informal only } & \multicolumn{1}{c|}{ Financially excluded } \\
\hline Nigeria & $38.3 \%$ & $10.3 \%$ & $9.8 \%$ & $41.6 \%$ \\
\hline Kenya & $42.3 \%$ & $33 \%$ & $7.2 \%$ & $17.4 \%$ \\
\hline Rwanda & $26.0 \%$ & $42.0 \%$ & $21.0 \%$ & $11.0 \%$ \\
\hline Togo & $18.0 \%$ & $27.0 \%$ & $15.0 \%$ & $40.0 \%$ \\
\hline Madagascar & $12.0 \%$ & $17.0 \%$ & $30.0 \%$ & $41.0 \%$ \\
\hline
\end{tabular}

Source: EFInA (2016). 
Table 2 shows the state of financial inclusion among countries in Africa by making comparison among five countries. It presents that the proportion of the adult population who are formally banked in Nigeria at $38.3 \%, 10.3 \%$ of the adult population have access to formal financial services and financial products not supplied by Deposit Money Banks. Moreover, 9.8\% of the adult population use the unregulated financial institutions like cooperatives, savings clubs. The proportion of the population that were financially excluded from formal financial service is $41.6 \%$ which is higher than the proportion included in the financial system.

Table 3. Comparison in terms of geo-political zone in Nigeria

\begin{tabular}{|l|r|r|r|r|r|r|}
\hline Geo-political Zone & North West & North East & $\begin{array}{c}\text { North } \\
\text { Central }\end{array}$ & South West & South South & South East \\
\hline Financially included & $24.0 \%$ & $25.0 \%$ & $48.0 \%$ & $78.0 \%$ & $55.0 \%$ & $59.0 \%$ \\
\hline Informal only & $6.0 \%$ & $14.0 \%$ & $14.0 \%$ & $4.0 \%$ & $14.0 \%$ & $13.0 \%$ \\
\hline Financially excluded & $70.0 \%$ & $62.0 \%$ & $39.0 \%$ & $18.0 \%$ & $31.0 \%$ & $28.0 \%$ \\
\hline
\end{tabular}

Source: EFInA (2016).

From Table 3 it was revealed that the South West geo-political zone is the most financially included in the financial system in Nigeria by $78 \%$ of the adult population, followed by the South East zone with a proportion of $59 \%$, followed by the South South with a proportion of $55 \%$ according to table 3 above. The North East zone has the lowest proportion of adult population that were included into the financial system by $24 \%$. Similarly, the South East zone also has the highest population of $70 \%$ that were financially excluded from accessing formal financial service. The South West zone has the lowest proportion of the adult population that were excluded from the financial system by $18 \%$. This means that the financially excluded adults are found in the North East and North West geo-political zones in Nigeria.

Poverty was reduced in India as a result of rural bank expansion policy (Burgess \& Pande, 2005). In an underdeveloped financial system, accessibility of funds is usually hard and people are usually restricted to their personal funds which leads to high cost of borrowing from the informal sector with the interest as high as $36 \%$ (e.g. moneylender), while accessibility of funds is allowed in a developed financial system. The poor are usually not included in the formal financial system as a result of their inability to provide the required collateral (World Bank, 2002). This makes them meet the informal sector for finance such as a moneylender who will lend to them at a very high rate (Kodan \& Chikara, 2011). 


\section{Research methodology}

The data used for this study are mainly time series from 2001 to 2016 as HDI explained by Amartya (2000) and computed by World Bank Indices, available for Nigeria from 2001 through 2016 only. The data for the study were converted from annual data to quarterly data due to inaccessibility of data for the periods prior to 2001 for variable HDI in Nigeria. Financial inclusion was adopted as the independent variable, while sustainable development was adopted as the dependent variable. Loan to rural areas (LRA), branch networks (BBranch), demand deposit from the rural areas (DRA) were adopted as proxies for financial inclusion and HDI was used as a proxy for the dependent variable

Voica (2017) in his study stressed the importance of financial inclusion. $\mathrm{He}$ viewed financial inclusion as a driver of social inclusion, social inclusion was viewed to be a driver of sustainable development and established that financial inclusion drives sustainable development.

HDI is used to measure the basic human development in an economy. It comprises of life expectancy at birth, expected year of schooling, mean year of schooling, and GNI per capita Human Development Report (2016).

\subsection{Model specification}

The main goal of Sustainable Development Goal (SDG) is to reduce the poverty level in the society which is usually measured by Human Development Index. HDI comprises of life expectancy, education and per capita income. This index is a good indicator for measuring sustainable development in any country. A high level of HDI signifies a better level of development and well-being of the people, whereas low HDI implies weak level of development and well-being of the people. Financial inclusion is measured by the number of bank branches (BBranch), demand deposit from the rural areas (DRA) and loan to rural areas (LRA). The choice of the variables selected for this study is hinged on the availability of data. Reduction in the number of BBranch will tend to prevent people from saving their money which could lead to a higher level of exclusion. Increase in the loan granted to the rural dwellers will help increase productivity and standard of living of the rural dwellers. DRA as an indicator helps ascertain the level of exclusion in an economy because an economy with low level of DRA indicates high level of financial exclusion (Onaolapo, 2015). 
Based on the discussion the following model was developed. The model adopted for this study is underpinned to the model of Kodan \& Chikara (2011) which used HDI to proxy financial inclusion.

The model to be used is expressed mathematically as thus:

$$
H D I=f(L R A, D R A, B B r a n c h)
$$

The econometrics model is written as:

$$
H D I=\alpha+\beta_{1} L R A+\beta_{2} D R A+\beta_{3} B \text { Branch }+e
$$

To adjust for disparity in unit and measurement so that it can conform to the homoscedastic assumption as clearly stated in the classical linear regression model, we log-linearise equation 3.2 to have equation 3.3

$$
H D I=\infty+\sigma \ln L R A+\mu \ln D R A+\psi \ln B \text { Branch }+e
$$

Where is constant, $\sigma, \mu$ and $\psi$ are the coefficient of the independent variable, while other variables remain as defined earlier. In determining the level of relationship in both the long-run and short run among the variables, the study used different econometric techniques. Characteristics of each variable were ascertained with the use of descriptive statistics, correlation matrix and unit root test. The study used both Error Correction Model and Fully Modified Ordinary Least Square (FMOLS) to ascertain both the short-run and long-run relationship respectively among the variables.

The a priori expectation of this model is that all the independent variables should have a positive relationship on the dependent variable (HDI). The mathematical expression is represented as; $\beta_{1}>0, \beta_{2}>0$ and $\beta_{3}>0$ implying that a unit increase in the independent variables will lead to increase in HDI by the value of the coefficient of the respective independent variable. Table 4 below describes the variables and their respective measurements.

Table 4. Variable description and measurement

\begin{tabular}{|l|l|l|l|}
\hline Type of variables & Variables & \multicolumn{1}{|c|}{ Description } & \multicolumn{1}{|c|}{ Measurement } \\
\hline (a) & (b) & (c) & (d) \\
\hline Independent & HDI & $\begin{array}{l}\text { Human Development } \\
\text { Index }\end{array}$ & $\begin{array}{l}\text { This is used to measure the basic human } \\
\text { development in an economy. WDI, 2016 }\end{array}$ \\
\hline & DRA & $\begin{array}{l}\text { Lean to rural area } \\
\text { the rural areas }\end{array}$ & $\begin{array}{l}\text { This is referred to amount of loan disbursed to } \\
\text { the rural area. CBN Statistical Bulletin, 2016 }\end{array}$ \\
\hline & BBranch & $\begin{array}{l}\text { Number } \\
\text { of commercial } \\
\text { bank branches }\end{array}$ & $\begin{array}{l}\text { This is used to measure the number of commercial } \\
\text { bank branches available in the country within the } \\
\text { period examined. The number of commercial bank } \\
\text { branches per 1,000 km2 (NBB) is used as financial } \\
\text { access indicator. CBN Statistical Bulletin, 2016 }\end{array}$ \\
\hline
\end{tabular}




\section{Research findings}

The descriptive statistic in Table 5 indicates that the average mean value of BBranch is $4,509.844$ which means that the average bank branch in Nigeria within the period under review is 4,509.844, the mean value of DRA is 20,966.87 which shows the average Demand Deposit from rural dwellers in Nigeria is $20,966.87$, the HDI of 0.457210 shows the average of HDI in Nigeria and the mean value of LRA is 121,225.0 shows the average Loan to rural areas in Nigeria within the period under review.

Table 5. Descriptive statistics

\begin{tabular}{|l|r|r|r|r|}
\hline \multicolumn{1}{|c|}{ Description } & \multicolumn{1}{c|}{ BBranch } & \multicolumn{1}{c|}{ DRA } & \multicolumn{1}{c|}{ HDI } & \multicolumn{1}{c|}{ LRA } \\
\hline Mean & $4,509.844$ & $20,966.87$ & 0.457210 & $121,225.0$ \\
\hline Median & $5,223.609$ & $10,177.69$ & 0.455000 & $20,733.30$ \\
\hline Maximum & $5,832.875$ & $100,937.70$ & 0.529031 & $970,841.00$ \\
\hline Minimum & $1,759.750$ & $-12,555.92$ & 0.386724 & $-93,308.83$ \\
\hline Std. Dev. & $1,198.808$ & $30,673.32$ & 0.040119 & $269,177.10$ \\
\hline
\end{tabular}

Source: Authors computation using E-views (2018).

Table 6. Correlation matrix of the datasets

\begin{tabular}{|l|r|r|r|r|}
\hline \multicolumn{1}{|c|}{ Variables } & \multicolumn{1}{c|}{ HDI } & \multicolumn{1}{c|}{ BBranch } & \multicolumn{1}{c|}{ DRA } & \multicolumn{1}{c|}{ LRA } \\
\hline HDI & 1.000000 & & & \\
\hline BBranch & 0.830352 & 1.000000 & & \\
\hline DRA & 0.355260 & 0.016035 & 1.000000 & \\
\hline LRA & 0.407423 & 0.345208 & -0.256230 & 1.000000 \\
\hline
\end{tabular}

Source: Authors computation using E-views (2018).

Table 6 above gives a preliminary idea of the relationship among Bank Branch (BBranch), Demand Deposit from rural dwellers (DRA), Human Development Index (HDI) and Loan to rural areas (LRA). The table shows that there is a strong positive relationship between HDI and BBranch; it also shows that there are a positive relationship between HDI and DRA and a positive relationship between HDI and LRA. The table shows that there are a weak positive relationship between BBranch and DRA and a positive relationship between BBranch and LRA. The table also shows that there is a negative relationship between DRA and LRA. 


\subsection{Unit root test of variables}

To analyse the effect of the independent variables on the dependent variable, the first thing to be done is to carry out stationary test on these variables. This will help ascertain the order of integration of the variables and avoid spurious results. This paper adopted Phillip-Perron test to do the unit root test of the variables. The result is shown in Table 7 below.

Table 7. Unit root test: Using Phillips-Perron test statistics

\begin{tabular}{|l|r|r|r|r|r|r|}
\hline Variable & $\begin{array}{c}\text { Level } \\
\text { T-Stat }\end{array}$ & $\begin{array}{c}\text { Critical } \\
\text { value } \\
\text { at 5\% }\end{array}$ & $\begin{array}{c}\text { First } \\
\text { Difference } \\
\text { T-Stat }\end{array}$ & $\begin{array}{c}\text { Critical } \\
\text { value at 5\% }\end{array}$ & $\begin{array}{c}\text { Order of } \\
\text { integration }\end{array}$ & $(\mathrm{C}, \mathrm{T}, \mathrm{K})$ \\
\hline BBranch & -2.40 & 2.908 & -3.45 & 2.909 & $1(1)$ & $(0,0,0)$ \\
\hline DRA & -1.31 & 2.908 & -4.07 & 2.909 & $1(1)$ & $(0,0,0)$ \\
\hline LRA & -2.27 & 2.908 & -3.71 & 2.909 & $1(1)$ & $(0,0,0)$ \\
\hline HDI & -0.61 & 2.908 & -2.75 & 2.909 & $1(1)$ & $(0,0,0)$ \\
\hline
\end{tabular}

Note: $(\mathrm{C}, \mathrm{T}, \mathrm{K})$ indicates the constant, trend and lag length in Phillip-Perron test.

Source: Authors computation using E-views (2018).

The result in Table 7 shows that all the variables are all stationary at 1(1). This enables us to know the type of regression estimation to conduct. From the unit root result, all the variables are stationary at first difference $1(1)$ at $5 \%$ significance level.

All the more so as the model for the unit root test is with intercept but without trend. The appropriate modus operandi of analysis that captures the combination of I(1) stationary variables according to (Johansen, 1991) is the ECM technique. The primary form of the dynamic ECM model is given as:

$$
\begin{aligned}
\Delta H D I=\beta_{0}+ & \sum_{s=1}^{n_{i}} \beta_{1} \Delta \ln L N G C F_{t-s}+\sum_{s=0}^{n_{i}} \beta_{2} \Delta \ln L R A_{t-s} \sum_{s=0}^{n_{i}} \beta_{4} \\
& +\sum_{\substack{s=0 \\
n_{i}}}^{n_{i}} \beta_{3} \Delta \ln D R A_{t-s}+\sum_{s=0}^{\varepsilon_{t}} \beta_{4} \Delta \ln B \operatorname{Branch}_{t-s}+\varphi \operatorname{ECM}(-1) \\
& +\cos _{t}
\end{aligned}
$$

Where $\Delta$ is the first difference operator, $n_{i}=(\mathrm{i}=1,2,3), \varphi$ is the coefficient of the error correction term, while other variables remain as defined earlier. The Error Correction Mechanism will indeed tell how much of deviation from the long run is being corrected in the short term. In order words, it gives the speed of adjustment from long-run equilibrium to the shortterm. 


\subsection{Optimal lag length selection}

The implication of the lag length selected explains the effect of the outcome of the previous year on the current year. The selection of an optimal lag length was very essential before carrying out a Johansen co-integration test, the result of which is presented in Table 8 .

Table 8. Optimal lag length selection criteria

\begin{tabular}{|c|r|r|r|r|r|r|}
\hline Lag & \multicolumn{1}{c|}{ LogL } & \multicolumn{1}{c|}{ LR } & \multicolumn{1}{c|}{ FPE } & \multicolumn{1}{c|}{ AIC } & \multicolumn{1}{c|}{ SC } & \multicolumn{1}{c|}{ HQ } \\
\hline 0 & -18.45200 & NA & 0.000291 & 3.207429 & 3.390017 & 3.190527 \\
\hline 1 & 39.64809 & $74.70012 *$ & $8.10 \mathrm{e}-07 *$ & $-2.806870 *$ & $-1.893931 *$ & $-2.891379 *$ \\
\hline 2 & 54.08083 & 10.30910 & $2.32 \mathrm{e}-06$ & -2.582976 & -0.939685 & -2.735092 \\
\hline
\end{tabular}

Notes: * indicates lag order selected by the criterion.

LR: Sequential modified LR test statistic (each test at 5\% level).

FPE: Final Prediction Error.

AIC: Akaike Information Criterion.

SC: Schwarz Information Criterion.

HQ: Hannan-Quinn Information Criterion.

Source: Authors computation using E-views (2018).

The result in Table 8 portrays different lag length criterion (LR, FPE, AIC, $\mathrm{SC}$ and $\mathrm{HQ}$ ). The Akaike Information Criterion depicting lag order length of (1) for the model is selected. After establishing the lag order length, the co-integration, and long-run equation results was estimated and explained in the next section.

\subsection{Johansen cointegration test result}

The cointegration test allows one to know the long-run parameter or equilibrium in the system with unit root variables (Rao, 2007). The overall result of the cointegration test shows that there is cointegration in the equation. The result shows that the variables have a long run relationship. The relationship is at $5 \%$ significance level based on the Trace statistics and Max-Eigen Statistics. The Trace statistics depicts that there is one (1) Co-integrating relationship among the variables, while the Max-Eigen Statistics also revealed that there is one (1) Co-integrating relationship among the variables. Therefore, there is a long run relationship among the variables. 
Table 9. Result of Johansen co-integration test based on trace statistic and max eigenvalue

\begin{tabular}{|l|r|r|r|r|r|r|r|}
\hline No. of CE(s) & $\begin{array}{c}\text { Trace } \\
\text { Statistic }\end{array}$ & $\begin{array}{c}0.05 \text { Critical } \\
\text { Value }\end{array}$ & Prob.** & No. of CE(s) & $\begin{array}{c}\text { Max-Eigen } \\
\text { Statistics }\end{array}$ & $\begin{array}{c}\text { 0.05 Critical } \\
\text { Value }\end{array}$ & Prob.** \\
\hline None $*$ & 56.20599 & 47.85613 & 0.0068 & None * & 34.82318 & 27.58434 & 0.0049 \\
\hline At most 1 & 21.38280 & 29.79707 & 0.3342 & At most 1 & 16.13135 & 21.13162 & 0.2173 \\
\hline At most 2 & 5.251450 & 15.49471 & 0.7816 & At most 2 & 4.086541 & 14.26460 & 0.8501 \\
\hline At most 3 & 1.164909 & 3.841466 & 0.2804 & At most 3 & 1.164909 & 3.841466 & 0.2804 \\
\hline
\end{tabular}

Notes: Trace test indicates 1 cointegrating eqn(s) at the 0.05 level.

* Denotes rejection of the hypothesis at the 0.05 level.

** MacKinnon, Haug, \& Michelis (1999) p-values.

Source: Authors computation using E-views (2018).

The result in Table 9 above depicts that there is a long-run relationship between the regressed and the regressors based on the rejection of the null hypothesis at $5 \%$ level of significance. The determination of the short run association is computed in the next section.

Table 10. Short-run estimation (Error Correction Model)

\begin{tabular}{|c|c|c|c|c|}
\hline Variable & Coefficient & Std. Error & t-Statistic & Prob. \\
\hline $\operatorname{ECM}(-1)$ & -0.025286 & 0.006169 & -4.098620 & 0.0001 \\
\hline $\mathrm{D}(\mathrm{HDI}(-1))$ & 0.265860 & 0.146283 & 1.817432 & 0.0750 \\
\hline $\mathrm{D}(\mathrm{HDI}(-2))$ & -0.054346 & 0.138706 & -0.391808 & 0.6968 \\
\hline $\mathrm{D}(\operatorname{lnBBranch}(-1))$ & -0.005669 & 0.008976 & -0.631637 & 0.5304 \\
\hline $\mathrm{D}(\operatorname{lnBBranch}(-2))$ & -0.000637 & 0.008194 & -0.077797 & 0.9383 \\
\hline $\mathrm{D}(\operatorname{lnDRA}(-1))$ & $-6.16 \mathrm{E}-05$ & 0.000419 & -0.147180 & 0.8836 \\
\hline $\mathrm{D}(\operatorname{lnDRA}(-2))$ & $-6.47 \mathrm{E}-05$ & 0.000410 & -0.157618 & 0.8754 \\
\hline $\mathrm{D}(\operatorname{lnLRA}(-1))$ & -0.000285 & 0.000560 & -0.509097 & 0.6129 \\
\hline $\mathrm{D}(\operatorname{lnLRA}(-2))$ & -0.000614 & 0.000651 & -0.944151 & 0.3495 \\
\hline $\mathrm{C}$ & 0.001794 & 0.000466 & 3.849048 & 0.0003 \\
\hline R-squared & 0.692424 & Mean dependent var & & 0.002144 \\
\hline Adjusted R-squared & 0.638146 & S.D. dependent var & & 0.002297 \\
\hline S.E. of regression & 0.001382 & Akaike info criterion & & -10.18245 \\
\hline Sum squared resid & $9.73 \mathrm{E}-05$ & Schwarz criterion & & -9.836408 \\
\hline Log likelihood & 320.5648 & Hannan-Quinn criter & & -10.04683 \\
\hline F-statistic & $12.75695 \mathrm{I}$ & Durbin-Watson stat & & 2.025278 \\
\hline Prob(F-statistic) & 0.000000 & & & \\
\hline
\end{tabular}

Source: Authors computation using E-views (2018). 
Table 10 represents the result of short-run estimates by using Error Correction Model (ECM). The estimated coefficient of the error correction vector is 0.025286 . This implies that ECM(-1) is the speed of adjustment towards equilibrium at the rate of 2.5286 per cent annually. The negative sign implies that there is co-integration among the variables. The negative significant vector shows that the vector is in line with the a priori expectation which is statistically significant. This means that there is short run causality running from BBranch, DRA and LRA to HDI. This means that $2.5286 \%$ of the previous year's disequilibrium in the economy is corrected in the short run which implies that adjustment of the deviation of the explanatory variable back to normality is not high.

The result revealed that the first period lag of HDI has positive insignificant relationship with HDI; the second period lag of HDI has a negative insignificant relationship with HDI. The first and second period lags of BBranch have negative insignificant relationship with HDI. The first and second period lags of DRA have negative insignificant relationship with HDI. The first and second period lags of LRA have negative insignificant relationship with HDI. The R-squared of $69.24 \%$ means that the independent variables were able to explain $69.24 \%$ variation in the dependent variable. The Adjusted R-squared of $63.81 \%$ shows that if additional variable is added to the independent variables, the independent variables will still be able to explain $63.81 \%$ variation in the dependent variable. The Durbin-Watson value of 2.02 indicates no serial autocorrelation among the explanatory variables in the model.

Table 11. Long-run estimation

\begin{tabular}{|l|r|r|r|r|}
\hline \multicolumn{1}{|c|}{ Variable } & \multicolumn{1}{c|}{ Coefficient } & \multicolumn{1}{c|}{ Std. Error } & \multicolumn{1}{c|}{ t-Statistic } & \multicolumn{1}{c|}{ Prob. } \\
\hline InBBrabch & 0.116005 & 0.017528 & 6.618116 & 0.0000 \\
\hline lnDRA & 0.004318 & 0.001468 & 2.941784 & 0.0047 \\
\hline InLRA & 0.008727 & 0.003391 & 2.573840 & 0.0126 \\
\hline C & -0.637280 & 0.143620 & -4.437277 & 0.0000 \\
\hline R-squared & 0.807250 & Mean dependent var & & 0.458329 \\
\hline Adjusted R-squared & 0.797449 & S.D. dependent var & 0.039422 \\
\hline S.E. of regression & 0.017742 & Sum squared resid & 0.018572 \\
\hline Long-run variance & 0.000985 & & \\
\hline
\end{tabular}

Source: Authors computation using E-views (2018).

Table 11 above explains the Fully Modified Least Squares (FMOLS) result. It was shown that a positive and significant relationship exist between HDI and BBranch in the long-run and there is a positive and significant relationship between HDI and Deposit in the long-run. It also revealed that a positive and sig- 
nificant relationship exists between HDI and Loan in the long-run. From the result it was disclosed that $80.72 \%$ of variations or changes in the dependent variable (HDI) can be explained by the independent variables which imply that the model has a goodness of fit because it is above $60 \%$. The Adjusted R-squared of $79.74 \%$ shows that if additional variable is added to the independent variable, the independent variable will still be able to explain $79.74 \%$ variation in the dependent variable.

A unit increase in BBranch will bring about 0.1160 increase in HDI and in DRA will bring about 0.0043 increase in HDI. Moreover, it increase in LRA will bring about 0.0087 increase in HDI. The model was used to test the null hypothesis which says that there is no significant relationship between sustainable development and financial inclusion in Nigeria. From the result it was observed that the regression result was significant; we therefore reject the null hypothesis and fail to reject the alternate hypothesis. It was shown that BBranch has a positive and significant relationship with HDI. This is because increase in the number of BBranch will enable more people to be involved in the financial system which will increase the rate of financial inclusion and will translate into sustainable development in Nigeria.

The result also revealed that DRA has a positive and significant relationship with HDI. This is because increase in amount of deposit by the rural dwellers will increase the lending capacity of the banks as well as the volume of loan and advances which the bank will offer to the entrepreneurs, thereby increasing their individual output and economic growth. This is in line with a priori expectation as well as the result from the study of Omojolaibi (2017) and Okoye, Kehinde, \& Olayinka (2017).

Also, it was revealed that LRA has a positive significant relationship with HDI. The higher the amount of credit advanced to the entrepreneurs, the higher the productive capacity which will contribute to human development in Nigeria. This result is also in line with the empirical finding of Okoye, Kehinde, \& Olayinka (2017) and Omojolaibi (2017) and the a priori expectation.

In other words, increase in BBranch will increase the rate of financial inclusion in Nigeria which is also in line with the a priori expectation as well as the work of Omojolaibi (2017), it will enable the rural dwellers to have access to formal financial services; it will increase the population of the adults who are financially included. Similarly, it will reduce the rate of adult exclusion in Nigeria. 
Moreover, increases in the amount of rural dwellers deposit with the commercial banks will improve the banks deposit. Increase in savings will translate into increase in investment which will in a long way contribute to the development of the nation. Increase in deposit will also increase the amount of loan which will also serve as source of finance to the potential entrepreneur, SMEs, MSMEs which will increase the productive capacity of the people. Increase in loan will reduce the poverty rate and increase the economic activities in the country. Lastly, the overall regression result shows that combination of all the variables jointly impacts on HDI which is in line with the result from the study of Kodan \& Chikara (2011).

\section{Conclusions}

The contribution of this study to the existing body of knowledge is that most previous works analysed the impact of financial inclusion on economic growth, but this work differs from the previous work because its main objective is to investigate the impact of financial inclusion on sustainable development in Nigeria.

Based on the above findings, it was discovered that branch bank in the rural area, demand deposit from the rural area and loan to the entrepreneurs all have positive significant impact on sustainable development in Nigeria. The implication of this is that the more bank branches, savings deposit and loan to entrepreneurs created in the country, the better the standard of living of the people in the country will be. The monetary authority through its policy should revise its policy at every interval in order to encourage establishment of banks, savings and issuance of credit to the entrepreneurs.

It is recommended that the banks and monetary authorities in Nigeria should pay attention to the establishment of bank branches, most especially, in the rural areas in order to get the rural dwellers involved in the formal financial system. The result of this study has revealed the importance of the establishment of bank branches in the rural areas as the reduction in the number of banks in the rural areas could increase the level of exclusion which could deter the level of development in the economy. The study also revealed that deposit mobilisation from the rural area would also contribute to the development of the economy. All the more so as low level of finance through loan to the rural dwellers could also slow the pace of development in an economy. Effort should be made towards providing sufficient credit for the rural dwellers as this will contribute to the sustainable development of the economy. 
Based on the findings above, the study recommends that banks and monetary authorities should develop new products and services that will attract savings from the rural dwellers because of the level of significance of their deposit to the development of the country. The authority should also renew financial products and services that are users friendly which will accommodate all the adults' population. This could be achieved by increasing the interest on deposit to the savers. Banks and the authority should also develop financial product in the form of loan and advances which will be given to the borrowers at a very low interest rate and make sure that the regulation on the financial institution is strengthened so as to ensure effective and efficient resources allocation in Nigeria.

The commercial banks should also ensure that the rural dwellers are provided with more bank branches, most especially, in areas where there are no banks. The rural dwellers should be orientated as regards the importance of their deposit to the development of the country. The monetary authority should ensure that the commercial banks establish branches, most especially, in the rural areas as this contributes to the development of the country. The monetary authority should also ensure that the policies made in the country always cater for the disadvantaged groups so that the level of financial exclusion will be reduced.

The future researchers could research to ascertain the impact of automated teller machine (ATM), point of sale terminal (POS), number of men and women using a payment product on sustainable development.

\section{References}

Aghion, P., \& Bolton, P. (1997, April). A theory of trickle-down growth and development. The Review of Economic Studies, 64(2), 151-172. https://doi.org/10.2307/ 2971707

Aker, J. C., Boumnijel, R., McClelland, A., \& Tierney, N. (2014). Payment mechanisms and anti-poverty programs: Evidence from a mobile money cash transfer experiment in Niger. Economic Development and Cultural Change, 65(1), 1-38. https://doi.org/10.1086/687578

Allen, F., Demirgüç-Kunt, A., Klapper, L., \& Martinez Peria, M. S. (2012, July). The foundations of financial inclusion: Understanding ownership and use of financial accounts. Journal of Financial Intermediation, 27(C), 1-30. https://doi.org/10.1016/ j.jfi.2015.12.003

Amartya, S. (2000). A decade of human development. Journal of Human Development, 1(1), 17-23. https://doi.org/10.1080/14649880050008746 
Amidžić, G., Massara, A., \& Mialou, A. (2014). Assessing countries' financial inclusion standing: A new composite index (Working Paper, No. 14/36). Washington, DC: International Monetary Fund.

Andrianaivo, M., \& Kpodar, K. (2011). ICT, Financial inclusion and growth: Evidence from African countries (Working Paper, WP/11/73). Washington, DC: International Monetary Fund. Retrieved from https://www.imf.org/external/pubs/ft/wp/2011/ wp1173.pdf

Aportela, F. (1999). Effects of financial access on savings by low-income people. Retrieved from http://users.nber.org/ rdehejia/!@\$devo/Lecture\%2006\%20Micro credit/supplemental/Aportela.pdf

De Arcangelis, G., Joxhe, M., McKenzie, D., Tiongson, E., \& Yang, D. (2015). Directing remittances to education with soft and hard commitments: Evidence from a lab-in-the-field experiment and new product take-up among Filipino migrants in Rome. Journal of Economic Behavior \& Organization, 111, 197-208. https://doi.org/ 10.3386/w2083910.1016/j.jebo.2014.12.025

Ashraf, N., Gons, N., Karlan, D., \& Yin, W. (2003). A review of commitment savings products in developing countries (ERD Working Paper, No. 46). Tokyo: Asian Development Bank. Retrieved from https:/www.adb.org/sites/default/files/publication /28185/wp045.pdf

Ashraf, N., Karlan, D., \& Yin, W. (2010). Female empowerment: Further evidence from a commitment savings product in the Philippines. World Development, 38(3), 333344. https://doi.org/10.1016/j.worlddev.2009.05.010

Attanasio, O., Augsburg, B., De Haas, R., Fitzsimons, E., \& Harmgart, H. (2011). Group lending or individual lending? Evidence from a randomised field experiment in Mongolia (MPRA Paper, No. 35439). London: European Bank for Reconstruction and Development. Retrieved from https:/www.ebrd.com/downloads/research /economics/workingpapers/wp0136.pdf

Banco Central do Brasil. (2010). Report on financial inclusion (No. 1). Retrieved from https://www.bcb.gov.br/Nor/relincfin/report_on_financial_inclusion_n1_2010.pdf

Banerjee, A., \& Newman, A. (1994, May). Poverty, incentives and development. American Economic Review Papers and Proceedings, 84(2), 211-215.

Banerjee, A., Duflo, E., Glennerster, R., \& Kinnan, C. (2015). The miracle of microfinance? Evidence from a randomized evaluation. American Economics Journal: Applied Economics, 7(1), 22-53. https://doi.org/10.1257/app.20130533

Beaman, L., Karlan, D., Thuysbaert, B., \& Udry, C. (2014). Self-selection into credit markets: Evidence from agriculture in Mali (Working Paper, No. 20387). Cambridge: National Bureau of Economic Research. Retrieved from https://data. nber.org/img/wp_icons/pdf.gif

Beck, T., Demirgüç-Kunt, A., \& Honohan, P. (2009). Access to financial services: Measurement, impact and policies. The World Bank Research Observer, 24(1), 119-145. https://doi.org/10.1093/wbro/lkn008 
Beck, T., Demirgüç-Kunt, A., Laeven, L., \& Maksimovic, V. (2006). The determinants of financing obstacles. Journal of International Money and Finance, 25(6), 932-952.

Beck, T., Demirgüç-Kunt, A., \& Levine, R. (2007). Finance, inequality and the poor. Journal of Economic Growth, 12(1), 27-49. https:/doi.org/10.1007/s10887-007-9010-6

Brune, L., Giné, X., Goldberg, J., \& Yang, D. (2015). Facilitating savings for agriculture: Field experimental evidence from Malawi (NBER Working Paper, No. 20946). Cambridge, MA: National Bureau of Economic Research. Retrieved from https://www.nber.org/papers/w20946.pdf

Burgess, R., \& Pande, R. (2005). Do rural banks matter? Evidence from the Indian social banking experiment. American Economic Review, 9(3), 780-795. https://doi.org/ $10.1257 / 0002828054201242$

Chima, O. (2011). Financial services still shallow in Africa. Retrieved from https:// allafrica.com/stories/201112190299.html

Demirguc-Kunt, A., Klapper, L., \& Singer, D. (2013). Financial inclusion and legal discrimination against women: Evidence from developing countries (Policy Research Working Paper, No. 6416). Washington, DC: World Bank. Retrieved from http://documents.worldbank.org/curated/en/801311468330257772/pdf/wps6416.pdf

Dupas, P., \& Robinson, J. (2013). Why don't the poor save more? Evidence from health savings experiments. American Economic Review, 103(4), 1138-1171. https://doi. org/10.1257/aer.103.4.1138

EFInA Survey. (2012). EFInA access to financial services in Nigeria 2012 survey. Qualitative phase. Retrieved from https://www.efina.org.ng/wp-content/uploads/2018/ 12/EFInA-A2F-2012-surveyFGDKey-Findings.pdf

EFInA Survey. (2014). EFInA access to financial services in Nigeria 2014 survey. Key findings. Retrieved from https://www.efina.org.ng/wp-content/uploads/2014/12/ EFInA-Access-to-Financial-Services-in-Nigeria-2014-Survey-Key-Findings.pdf

EFInA Survey. (2016). EFInA access to financial services in Nigeria 2016 Survey. Key findings: Profile of the informally served population. Retrieved from https:// www.efina.org.ng/wp-content/uploads/2019/02/Did-You-Know-Series-Eight.pdf

Emas, R. (2015). The concept of sustainable development: Definition and defining principles. Miami: Florida International University.

Financial inclusion and financial stability: Are they two sides of the same coin? (2011). Address by Shri H. R. Khan, Deputy Governor of the Reserve Bank of India, at BANCON 2011, organized by the Indian Bankers Association and Indian Overseas Bank, Chennai, India, 4 November. Retrieved from https://www.bis.org/review/ r111229f.pdf

Fink, G., Kelsey, J. B., \& Masiye, F. (2014). Seasonal credit constraints and agricultural labor supply: Evidence from Zamia (Working Paper, No. 20218). Cambridge, MA: National Bureau of Economic Research. 
Frenk, J., \& Knaul, F. M. (2002). Health and the economy: Empowerment through evidence. Bulletin of the World Health Organization, 80(2). Retrieved from https://apps.who.int/iris/bitstream/handle/10665/71225/80\%282\%2988.pdf?sequen ce $=1 \&$ isAllowed $=y$

Galor, O., \& Zeira, J. (1993). Income distribution and macroeconomics. The Review of Economic Studies, 60(1), 35-52. https://doi.org/10.2307/2297811

Greenwood, J., \& Jovanovic, B. (1990). Financial development, growth and the distribution of income. The Journal of Political Economy,98(5), 1076-1107. https://doi.org/ $10.1086 / 261720$

Hannig, A., \& Jansen, S. (2010). Financial inclusion and financial stability: Current policy issues (Working Paper Series, No. 259). Chiyoda, Tokyo: Asian Development Bank Institute.

Human Development Report. (2016). Briefing note for countries on the 2016. New York, NY: Author.

Ibeachu, E. H. (2010). Comparative analysis of financial inclusion: A study of Nigeria and the UK (Unpublished master degree thesis). Leeds Metropolitan University, Leeds, UK.

IFC. (2011). Strengthening access to finance for women-owned SMEs in developing countries. Washington, DC: International Finance Corporation and Global Partnership for Financial Inclusion. Retrieved from https:/www.ifc.org/wps/wcm/connect /2a9123b3-d369-4115-8cbf-19083218ce64/G20_Women_Report.pdf?MOD= AJPERES\&CVID=jqeI-xk

IMF. (2015). Ending poverty and sharing prosperity (Global monitoring report 2014/2015). Washington, DC: Author. Retrieved from http://pubdocs.worldbank. org/en/637391444058280425/GMR-2014-Full-Report.pdf

Islam, M. E., \& Al Mamun, M. S. (2011). Financial inclusion: The role of Bangladesh bank (Working Paper Series, WP 1101). Dhaka: Research Department, Bangladesh Bank.

Jack, W., \& Suri, T. (2014). Risk sharing and transactions costs: Evidence from Kenya's mobile money revolution. American Economic Review, 104(1), 183-223. https:// doi.org/10.1257/aer.104.1.183

Johansen, S. (1991, November). Estimation and hypothesis testing of cointegration vectors in Gaussian vector autoregressive models. Econometrica, 59(6), 1551-580. Retrieved from https:/www.jstor.org/stable/pdf/2938278.pdf

Karlan, D., Ratan, A. L., \& Zinman, J. (2014). Savings by and for the poor: A research review and agenda. Review of Income and Wealth, 60(1), 36-78. https://doi.org/ 10.1111/roiw.12101

Kempson, E., Atkinson, A., \& Pilley, O. (2006). Policy level response to financial exclusion in developed economies: Lessons from developing countries. Bristol: Personal Finance Research Centre, University of Bristol.

King, R., \& Levine, R. (1993, December). Finance, entrepreneurship, and growth. Journal of Monetary Economics, 32(3), 513-542. https://doi.org/10.1016/0304-3932(93) 90028-E 
Klapper, L., El-Zoghbi, M., \& Hess, J. (2016). Achieving the sustainable development goals: The role of financial inclusion. New York, NY: UNSGSA.

Kodan (Kablana), A. S., \& Chikara, K. S. (2011). A theoretical and quantitative analysis of financial inclusion and economic growth. Management and Labour Studies, 38(1\&2), 103-133. htpps://doi.org/10.1177/0258042X13498009

Krishna, A. (2006, February). Pathways out of and into poverty in 36 villages of Andhra Pradesh, India. World Development, 34(2), 271-88. https://doi.org/10.1016/ j.worlddev.2005.08.003

MacKinnon, J. G., Haug, A. A., \& Michelis, L. (1999). Numerical distribution functions of likelihood ratio tests for cointegration. Journal of Applied Econometrics, 14, 563-577. https://doi.org/10.1002/(SICI)1099-1255(199909/10)14:5\%3C563::AIDJAE530\%3E3.0.CO;2-R

Malhotra, A., Kanesathasan, A., \& Patel, P. (2012). Connectivity: How mobile phones, computers and the internet can catalyze women's entrepreneurship. India: A case study. Washington, DC: International Center for Research on Women and Cherie Blair Foundation for Women. Retrieved from https://www.icrw.org/wpcontent/uploads/2016/10/Connectivity-how-mobile-phones-computers-and-theinternet-can-catalyze-womens-entrepreneurship.pdf

de Mel, S., McKenzie, D., \& Woodruff, Ch. (2014, January). Business training and female enterprise start-up, growth and dynamics: Experimental evidence from Sri Lanka. Journal of Development Economics, 106, 199-210. https://doi.org/10.1016/ j.jdeveco.2013.09.005

Milanovic, B. (2012). Global income inequality by the numbers: In history and now (Policy Research Working Paper, No. 6259). Washington, DC: World Bank. Retrieved from http://documents.worldbank.org/curated/en/959251468176687085/ pdf/wps6259.pdf

Muhammed, S. A., \& Wei, J. (2014). Financial inclusion and challenges in Tanzania. Research Journal of Finance and Accounting, 5(21), 2222-1697.

Morduch, J. (2007). The unbanked: Evidence from Indonesia. The financial access initiative. New York: The Financial Access Initiative and NYU Wagner Graduate School. Retrieved from https://wagner.nyu.edu/files/faculty/publications/2007-03The-Unbanked-JM.pdf

Muralidharan, K., Niehaus, P., \& Sukhtankar, S. (2014). Building state capacity: Evidence from biometric smartcards in India (Working Paper, No. 19999). Cambridge, MA: NBER. Retrieved from https://econweb.ucsd.edu/ pniehaus/papers /statecapacity.pdf

National Financial Inclusion Strategy. (2012). Financial inclusion in Nigeria. Summary report. Abuja, Nigeria: Roland Berger Strategy Consultant. Retrieved from https://www.cbn.gov.ng/Out/2012/publications/reports/dfd/CBN-Summary\%20 Report\%20of-Financial\%20Inclusion\%20in\%20Nigeria-final.pdf

Nigeria Bureau of Statistics. (2010). Retrieved from www.nigerianstat.gov.ng 
Okoye, L. U., Kehinde, A. A., Olayinka, E., \& Modebe, M. J. (2017). Financial inclusion: A panacea for balanced economic development. Paper presented at 28th IBIMA Conference: "Theme-Vision 2020: Innovation Management, Development Sustainability, and Competitive Economic Growth”, November 9-10, 2016, Seville, Spain.

Omojolaibi, J. A. (2017, February). Financial inclusion, governance and economic progress in Nigeria: What happens to the welfare of the poor? Arabian Journal of Business and Management Review (Oman Chapter), 6(7), 72-85. Retrieved from https:/www.arabianjbmr.com/pdfs/OM_VOL_6_(7)/3.pdf

Onaolapo, A. R. (2015). Effects of financial inclusion on the economic growth of Nigeria. International Journal of Business and Management Review, 3(8), 11-28. Retrieved from http://www.eajournals.org/wp-content/uploads/Effects-of-FinancialInclusion-on-the-Economic-Growth-of-Nigeria-1982-2012.pdf

O’Neill, D. (1995). Education and income growth: Implications for cross-country inequality. Journal of Political Economy, 103(6), 1289-1301.

Pande, R., Cole, S., Sivasankaran, A., Bastian, G., \& Durlacher, K. (2012). Does poor people's access to formal banking services raise their income? London: EPPICentre, Social Science Research Unit, Institute of Education, University of London.

Pannarunothai, S., \& Mills, A. (1997, June). The poor pay more: Health-related inequality in Thailand. Social Science \& Medicine, 44(12), 1781-1790. https://doi.org/ 10.1016/s0277-9536(96)00287-0

Priyanka, S., Xu, K., \& Evans, D. B. (2011). Impact of out-of-pocket payments for treatment of non-communicable diseases in developing countries: A review of literature (Discussion Paper, No. 2). Geneva: World Health Organization. Retrieved from https://www.who.int/health_financing/documents/dp_e_11_02-ncd_finburden. pdf?ua $=1$

Rao, B. B. (Ed.). (2007). Cointegration: For the applied economist. London: Palgrave Macmillan UK.

Reserved Bank of India [RBI]. (2008, July). Master circular-credit card operations of banks. DBOD.FSD.BC.6/ 24.01.011/ 2008-09. Retrieved from https:/www.rbi. org.in/Scripts/BS_CircularIndexDisplay.aspx?Id=4309

Sacerdoti, E. (2005). Access to bank credit in Sub-Sahara Africa: Key issue and reform strategies (Working Paper, No. 05/166). Washington, DC: Interaction Monetary Fund. Retrieved from https://www.imf.org/external/pubs/ft/wp/2005/wp05166.pdf

Sain, M. R. M., Rahman, M. M., \& Khanam, R. (2016). Financial exclusion in Australia: Can Islamic finance minimise the problem? Australasian Accounting, Business and Finance Journal, 10(3), 89-104. https://doi.org/10.14453/aabfj.v10i3.6

Schumpeter, J. A. (1911). The theory of economic development. Cambridge, MA: Harvard University Press.

Shankar, S. (2013). Financial inclusion in India: Do microfinance institutions address access barriers? ACRN Journal of Entrepreneurship Perspectives, 2(1), 60-74. Retrieved from http://www.acrn.eu/resources/Journals/201302d.pdf 
Somoye, R. O. C. (2018). Multicratic finance, fiscal governance and sustainable development: Where does the money go? Unpublished inaugural lecture presentation, Olabisi Onabanjo University, Ago-Iwoye, Ogun State, Nigeria.

United Nation. (2017). The sustainable development goals report 2017. United Nations publication issued by the Department of Economic and Social Affairs (DESA). Retrieved from https://www.un.org/development/desa/publications/sdg-report-2017.html

Voica, M. C. (2017, June). Financial inclusion as a tool for sustainable development. Romanian Journal of Economics, 44(1(53)), 121-129.

Women's World Banking. (2012). Microfund for women's caregiver experience: Lessons from Jordan on health microinsurance. In partnership with Credit Suisse. New York: Author. Retrieved from http://www.womensworldbanking.org/wp-content/ uploads/2013/02/InsuranceResReport_Web.pdf

World Bank. (2001). Finance for growth: Policy choices in a volatile world (Policy Research Report, No. 1). Washington DC: Author and New York: Oxford University Press. Retrieved from http://documents.worldbank.org/curated/en/3411514 68762914798/pdf/multi0page.pdf

World Bank. (2002). Year in review (World Bank Annual Report, No. 24908, Vol. 1). Washington DC: Author. Retrieved from http://documents.worldbank.org/curated/ en/379051468163155729/pdf/multi0page.pdf

World Bank. (2008). Banking the poor: Measuring banking access in 54 economies. Washington, DC: Author. Retrieved from http://documents.worldbank.org/curated/ en/608761468157765351/Banking-the-poor-measuring-banking-access-in-54economies

World Bank. (2014). Financial inclusion (Global Financial Development Report, No. 82556). Washington, DC: Author. Retrieved from http://documents.worldbank.org/ curated/en/225251468330270218/pdf/Global-financial-development-report-2014financial-inclusion.pdf

World Bank. (2015). Gender equality, poverty reduction, and inclusive growth (World Bank Group Gender Strategy (FY16-23)).Washington, DC: Author. Retrieved from http://documents.worldbank.org/curated/en/820851467992505410/pdf/102114REVISED-PUBLIC-WBG-Gender-Strategy.pdf 